\title{
Jacqueline Vayntrub* \\ The Book of Proverbs and the Idea of Ancient Israelite Education
}

DOI 10.1515/zaw-2016-0009

\section{Introduction ${ }^{1}$}

In an examination of ancient Mediterranean cultural values, the relationship between literary craft and education is neither self-evident nor is it free from debate. One position reflected in ancient Greek texts is that mastery of literary traditions is an educational ideal. In Plato's Protagoras, the eponymous protagonist - an educator by trade - claims the most important element of an individual's education is the mastery of the poetic tradition, the skill in recalling the tradition and discerning the values expressed by the words. ${ }^{2}$ In Xenophon's Symposium, Niceratus claims his father had educated him to be a good man, meaning, »he compelled me to memorize all of Homer. $«^{3}$ But there is another position on the relationship between poetry and education articulated in these very same texts, that the mastery of poetic traditions - specifically the deployment of the words of others - detracts from knowledge. ${ }^{4}$ Bracketing the problematic task of defining

1 I would like to acknowledge those who read and commented upon previous versions of this article. Thanks are due to Francis Borchardt, Alexander Forte, Charles Huff, Joseph Lam, David Lambert, Mark Leuchter, Nathan Mastnjak, Eva Mroczek, Gregory Nagy, Dennis Pardee, William Schniedewind, and Stephen Young. A version of this study was prepared and distributed for the Fifth Enoch Nangeroni Seminar in Naples, Italy, July 2015, supported by a grant from the University of Chicago Center for Jewish Studies and mentioned for the 2015 Luckens International Prize in Jewish Thought and Culture.

2 Plato, Protagoras 339a. Here, and below, I refer to poetry following Barbara Herrnstein Smith, »Poetry in the broad sense, « New Directions in Literary History (1974): 165-187.

3 Xenophon, Symposium III. 5, trans. O.J. Todd (1923).

4 In Xenophon's Symposium, Antisthenes responds to Niceratus that the rhapsodes, the stupidest category of men, have also mastered these poems, and Socrates rescues Niceratus from association with the rhapsodes by claiming that the rhapsodes "do not know the inner meaning of the poems «, while presumably Niceratus does (III. 6). In Protagoras, following Socrates' exposition of the poem of Simonides, Hippias suggests performing a discourse on the poem, to which Socrates declines and insists to turn the conversation away from poetry: »And so a gathering like

*Kontakt: Jacqueline Vayntrub, Department of Near Eastern Languages and Civilizations, 6 Divinity Ave, Room 106, Cambridge, MA 02138, vayntrub@g.harvard.edu 
both > poetry and seducation ‘ for the moment, we may be able to observe that the project of defining the nature of the relationship between these two activities is widely attested in texts foundational to the Western philosophical canon and has shaped much of the discourse of literary criticism. ${ }^{5}$ It is therefore surprising that biblical scholarship, a participant within this tradition of intellectual history and a direct descendant of the neoclassical study of ancient texts, has uncritically relied upon a literary anthology, the book of Proverbs, as a primary data set in the recovery of ancient Israelite and Judean educational values and practices. ${ }^{6}$

this of ours ... requires no extraneous voices, not even of the poets, whom one cannot question on the sense of what they say ... No, this sort of meeting is avoided by men of culture, who prefer to converse directly with each other, and to use their own way of speech in putting one another by turns to the test. «347a-348a.

5 Questions of the educational role of poetry as articulated in Plato have much to do with historical developments in the performance traditions of poetry, and, as Gregory Nagy informs us on views long considered >classical positions, »Plato is the champion of a new education where dialogue supplants the primacy of poetry". See »Early Greek Views of Poets and Poetry, « in The Cambridge History of Literary Criticism, vol. 1: Classical Criticism, ed. George Alexander Kennedy (Cambridge: Cambridge University Press, 1990): 1-77, here 75. It may be more productive to think of the relationship between seducation « and `poetry in performance cultures such as those producing early Greek poetry as reflections of particular perspectives on the appropriateness and social value of performing poetry. See also Giovanni R. F. Ferrari, »Plato and Poetry, « in The Cambridge History of Literary Criticism, vol. 1: 92-148, here 99-103. For the recapitulation of these concerns in the neoclassical study of ancient languages (including Hebrew) and the emergence of a corresponding philosophy of language, see Richard Waswo, »Theories of Language, « in The Cambridge History of Literary Criticism, vol. 3: The Renaissance, ed. Glyn P. Norton (Cambridge: Cambridge University Press, 1999), 25-35 and William J. Kennedy, »Humanist Classifications of Poetry among the Arts and Sciences, « in The Cambridge History of Literary Criticism, vol. 3: 91-97. 6 See discussion of past and current scholarship in the subsequent section of this study. James L. Crenshaw's monograph on the topic, Education in Ancient Israel: Across the Deadening Silence (New York: Doubleday, 1998), for example, relies on Proverbs to inform educational values and practices. In attempting to sort out the available evidence informing sformal educationak institutions, Crenshaw follows Golka's conclusions on the social reality of ancient Israel based on the representation of education in Proverbs, that education in ancient Israel "presupposes a so-called master-apprentice system « in: The Leopard's Spots: Biblical and African Wisdom in Proverbs (Edinburgh: T\&T Clark, 1993), $10 \mathrm{f}$. Crenshaw argues: »Most if not all such training was oral, the oral generation passing along to the youth a wealth of insights it had gained through wide experience. The proverbial sayings in the Book of Proverbs encapsulate such instruction, which combined practical and moral learning «, 86. Such a conclusion does not take into account the ways in which texts qua literature engage literary ideals or inherited traditions and may not in fact reflect normative practices. Most recently, Nili Shupak's article, »Learning Methods in Ancient Israel, « evidences such activity, Vetus Testamentum 53/3 (2003): 416-426. Shupak is careful to state at the outset of her study that »[No] school literature, such as that discovered in Mesopotamia and Egypt, which sheds light on the school milieu, the material learned and the schooling methods, been uncovered, « and concedes that it is »in absence of such evidence« that 
The various positions I have recalled above on literary craft and its valuation as a mode of knowledge production are debates reflected in ancient Greek literature. Such explicit positions do not emerge from the biblical literary materials. ${ }^{7}$ When speaking about the extent to which the Book of Proverbs reflects social and cultural practices and institutions, we must keep its literary character and self-presentation in mind. ${ }^{8}$ While literary works can reflect the values and practices of a culture, they are not mirror images of these realities. Literature refracts values and practices through its aesthetic, engaging traditions and reshaping them. This study therefore aims to disentangle the literary self-presentation of the Book of Proverbs from its use in scholarly reconstruction of ancient Israelite and Judean educational practices or institutions.

In the first half of the 20th century, the discovery of ancient Near Eastern instructional texts that share lexical, thematic, and structural features with the book of Proverbs ${ }^{9}$ - along with the guiding assumptions of form criti-

»the Bible serves as a primary information source for ... reconstruct[ing] the methods and stages of learning « in ancient Israel. Citing her own previous studies, Where Can Wisdom Be Found? The Sage's Language in the Bible and in Ancient Egyptian Literature, OBO 130 (Fribourg: University Press/Göttingen: Vandenhoeck \& Ruprecht, 1993) and »The Sitz im Leben of the Book of Proverbs in the Light of Comparison of Biblical and Egyptian Wisdom Literature, « Revue Biblique 94 (1987): 98-119, Shupak asserts that Proverbs »belonged to the corpus of studies in the ancient educational framework. « However, beyond form-critical (and evolutionary literary) assumptions of the social context out of which such a hypothetical soriginal form ‘ arose, there exists no available data on the social or educational function of the biblical book of Proverbs (or any of its parts) during its composition or collection to make such a claim. The social function of Proverbs (or any other literary text, for that matter) cannot be determined given the available evidence; an evaluation of Proverb's literary self-presentation, is however possible.

7 Or, at least positions on the relationship between literary production and education are not articulated in a form comparable to the theoretical discussions in ancient Greek literature. As this study will suggest, a position on this relationship may be read in the framing and organization of Proverbs.

8 Similarly, Raymond C. van Leeuwen argued that »The intuition of a literary unity, especially of poetry takes place through a process of intuition or apperception of elements which somehow belong together, albeit complexly « and that »In the combination and arrangement of these forms [in Proverbs] we may find that the meaning of the whole is more than the sum of its parts, " Context and Meaning in Proverbs 25-27, SBL Dissertation Series 96 (Atlanta: Scholars Press, 1988), 35; 37. 9 Commentaries on Proverbs prior to both Erman's and Gressman's 1924 publications on the relationship between the Instruction of Amenemope and Prov 22,17-24,22 - A. Erman, »Eine ägyptische Quelle der `Sprüche Salomos, « in Sitzungsberichte der Preussischen Akademie der Wissenschaften, phil.-hist. Kl. 15 (1924): 86-93; Hugo Gressman, „Die neugefundene Lehre des Amen-em-ope und die vorexilische Spruchdichtung Israels, « ZAW 42 (1924): 272-296 - did not understand Proverbs to be an exemplum of an ancient literary sinstruction genre. To cite an example, Crawford H. Toy's 1899 commentary does not engage a comparison between Proverbs 
$\operatorname{cism}^{10}$ - prompted a reexamination of the literary forms of the book of Proverbs as a reflection of ancient Israelite educational practices and institutions. These ancient Near Eastern instructional compositions all share a particular compositional device: a transmission narrative framing the sinstructions ‘ themselves, wherein these framed instructions are depicted as the explicitly quoted speech of the named and famed transmitter. The frame narrative of trans-generational transmission and speech performance is essential to the text's authorization as efficacious instructions. The book of Proverbs, in its present form, is lacking such an overarching frame narrative, and the attribution to Solomon does not mark the following discourse as his quoted speech. This peculiar framing of the book of Proverbs sets the anthology apart from other ancient Near Eastern didactic compositions - the very texts Proverbs has been argued to resemble in its literary presentation. As a result, Proverbs cannot be argued to transparently inform an educational Sitz im Leben. ${ }^{11}$

The peculiar literary presentation of Proverbs as compared to other ancient Near Eastern instructional compositions, can, however, show how the authors and editors giving the book its final shape engaged the values of their literary culture. Namely, values of poetic and literary craft - particularly the value of trans-generational performance and transmission of knowledge claims - are engaged by the book's framing and organization, that the book's final form advances a particular position on the relationship between literary production (poetic craft, performing traditional $>$ texts $\triangleleft$ ) and literary transmission (education).

and any of the works of Hesiod, though this material was available in Toy's day and Works and Days is now generally acknowledged to be within the sinstruction « genre broadly, and instead offers a comparison to the proverb traditions of other peoples. See A Critical and Exegetical Commentary on the Book of Proverbs (Edinburgh: T\&T Clark, 1899), xxxvi. Erman's publication was followed by a number of studies comparing Proverbs generally to ancient Egyptian and Mesopotamian sinstruction texts, and this practice of reading Proverbs as an sinstruction $>$ text became conventional in scholarship. See discussion below.

10 The primary guiding assumption of Formgeschichte, which inherited a pre-Romantic conceptual scheme of the development of language, is that literary forms change as they move through different historical and social contexts. Its goal, thus, is to reconstruct the history of literary forms through its assumption that the earliest literary forms originate in a purely oral setting and secondarily undergo change and complexity through their interaction with other forms and in their transformation in the textual medium. In the form-critical approach, classically conceived, by > paring down « literary texts to their original simplistic form one can access the original social context which gave rise to the form. See Martin J. Buss, Biblical Form Criticism in Context, JSOTSup 274 (Sheffield: Sheffield Academic Press, 1999), 232f. and 358-368, especially 358f. and Martin Rösel, »Formen/Gattungen. II. Altes Testament, « in RGG 3 (2000): 186-190.

11 Contra Shupak, »The Sitz im Leben of the Book of Proverbs «: 98-119. 


\section{The problem with looking for educational institutions and practices in the book of Proverbs}

Proverbs has long served biblical scholarship as a primary source of data for reconstructing the educational practices and institutions of ancient Israel, without consideration of the fact that the book of Proverbs presents itself as a curated anthology of poetry whose literary purpose is not immediately evident. ${ }^{12}$ This is especially evident in scholarship operating within a form-critical framework. Within this conceptual framework, scholarship has divided along two lines: (1) Proverbs originates in written literature, produced by an ancient Israelite wisdom school which responded to and reshaped foreign (specifically Egyptian) instruction texts; ${ }^{13}$ (2) Proverbs originates from oral, home-grown wisdom, and the book's literary forms can be studied diachronically by tracing a form to its original lived context. ${ }^{14}$ In both of these perspectives, the book of Proverbs itself transparently informs cultural practices and institutions. In the reading of Proverbs as the fruits of »scholastic wisdom, « an examination of the text can yield details of historical scribal and educational institutions. In the reading of Proverbs as a collection of originally oral folk wisdom, the assumption is that a reading of the text can aid reconstruction of oral pedagogical materials and prac-

12 August Klostermann’s 1908 article, »Schulwesen im alten Israel, « in Festschrift Theodor Zahn (Leipzig: A. Deichert, 1908): 193-232 is perhaps the earliest example of this practice, though his study did not operate under the same form-critical conclusions generated by the systematic comparison of Proverbs to Egyptian instruction texts, a scholarly approach initiated by the studies of Erman and Gressman comparing Amenemope to Proverbs, published in 1924. Klostermann admits that the evidence from the biblical texts is meager for a reconstruction of social practices: »Wer auf die berechtigten Fragen nach der weltlichen Kultur [Antworten sucht] ... wird bald zu der Empfindung kommen, dass er sich in einer erheblich ungünstigeren Lage befindet als die, welche die gleiche Forschung auf andere alte Kulturvölker richten«, 193. He describes the biblical texts as a fragmentary picture of ancient Israelite practices and institutions, but nevertheless one which is capable of illuminating the actual world in which the authors operated. According to Klostermann especially the lectures in the first nine chapters illustrate actual practices of educating the youth, 207.

13 The work of Gerhard von Rad, Weisheit in Israel (Neukirchen-Vluyn: Neukirchener Verlag, 1970); English translation: Wisdom in Israel, trans. by James D. Martin (London: SCM Press/ Valley Forge: Trinity Press International, 1972) and Hans-Jürgen Hermisson, Studien zur israelitischen Spruchweisheit (Neukirchen-Vluyn: Neukirchener Verlag des Erziehungsvereins, 1968), are examples of this view.

14 The work of Golka, The Leopard's Spots and Claus Westermann, Wurzeln der Weisheit: die ältesten Sprüche Israels und anderer Völker (Göttingen: Vandenhoeck \& Ruprecht, 1990); English translation: Roots of Wisdom: The Oldest Proverbs of Israel and Other Peoples (Louisville: Westminster John Knox Press, 1995) are examples of this view. 
tices. Both perspectives neglect the artifactual nature of such a highly organized and curated anthology and the potential gains of limiting examination of the text to its literary self-presentation.

Von Rad, in his highly influential Weisheit in Israel, ${ }^{15}$ stated the scholastic approach plainly: »Wir nehmen die Stoffe so, wie sie von den Sammlern dargeboten werden, und in dieser Gestalt haben wir Grund, sie als Schulweisheit zu verstehen. ${ }^{16}$ In Gesammelte Studien zum Alten Testament, von Rad argues that the forms in Proverbs were specifically the product of literate, pedagogical circles. ${ }^{17}$ Robert B. Y. Scott, in his commentary on Proverbs and Ecclesiastes argued explicitly for the "pedagogic purpose« of Proverbs and its articulation of normative positions on $»$ wisdom. ${ }^{18}$ According to Scott, Proverbs is »a source book of instructional materials for use in a school or in private study, for the cultivation of personal morality and practical wisdom. ${ }^{19}{ }^{19}$ William McKane, in his commentary, assumed that the Book of Proverbs has a popular origin as didactic literature, that its original form was not poetry, the present form of the book, however, is a result of the »influence of poetry and a form of elevated speech on [wisdom] literature. ${ }^{20}$

André Lemaire, in his study of ancient Israelite educational institutions and its relationship to the formation of the biblical materials, maintained that the discovered similarities of Prov 22,17-23,12 to the Egyptian Instructions of Amenemope forces scholars to consider the Sitz im Leben of the various collections of Proverbs and argues for a specific historical context. ${ }^{21}$ Namely, Lemaire argued that Prov

15 Von Rad's Weisheit in Israel and its English translation Wisdom in Israel is cited in more than a hundred studies in biblical wisdom literature, and in nearly every biblical wisdom study published after 1970 that has been cited in the present study. By contrast, Hermisson's study, though it anticipated von Rad's by two years, is not nearly as frequently cited.

16 Von Rad, Weisheit in Israel, 24. In English translation, »We accept the material [in Proverbs] as it is presented by the collectors, and we are justified in understanding it, in that form, as school wisdom, «Wisdom in Israel, 12. Hermisson argues the same for the material of Prov 10-22,16 and 25-29, Studien zur israelitischen Spruchweisheit, 40-44. See similar lines of argumentation by Bernhard Lang, Wisdom and the Book of Proverbs: An Israelite Goddess Redefined (New York: Pilgrim Press, 1986): »It remains indisputable that the book of Proverbs originated in the [wisdom] school and was being read there«, 10.

17 Gerhard von Rad, Gesammelte Studien zum Alten Testament, Theologische Bücherei 8 (München: Kaiser Verlag 1958); English translation: The Problem of the Hexateuch and Other Essays, trans. by Eric W. Trueman Dicken (New York: McGraw-Hill, 1966), $203 \mathrm{f}$.

18 Robert B.Y. Scott, Proverbs. Ecclesiastes, AB 18 (Garden City: Doubleday, 1965), xxxii-xxxv.

19 Ibid., 3.

20 William McKane, Proverbs: A New Approach (London: SCM Press, 1970), 1f. In Prophets and Wise Men (1965), McKane assumes an explicit literary origin for the book, 44.

21 André Lemaire, Les Écoles et la Formation de la Bible dans l'Ancien Israël, OBO 39 (Vandenhoeck \& Ruprecht: Göttingen, 1981), 42. 
10-22,16, as >collection of proverbs` »a probablement servi de recueil de proverbes pour l'enseignement dans les écoles du sud « and Prov 25-29, »représent probablement un recueil de proverbes passés du nord au sud au moment de la chute de Samarie. «22 Lemaire’s reconstruction of ancient Israelite education followed from this historical assumption, since the Book of Proverbs is, in his view, a transparent reflection upon and product of such an institution. ${ }^{23}$

David Carr's recent scholarship argues that ancient author-scribes internalized large amounts of text and attempted to faithfully transmit literary units in their textual compositions. ${ }^{24}$ In his 2005 work, Writing on the Tablet of the Heart, Carr offers a disclaimer that »Proverbs was not written to provide us data on such a process of education and enculturation. ${ }^{25}$ At the same time, however, Carr justifies his examination of the work to support his theory, arguing that »we find reflections in Proverbs of a similar, writing-supported process of shaping young Israelites. ${ }^{26}$ If Proverbs is not a transparent source for data on ancient knowledge production, as Carr was correct to point out in his 2005 work, how can it nevertheless serve as support for Carr's theory of the formation (the »reproduction" or »reconstruction «) of these texts from the memory of the authors? Indeed, in his more recent The Formation of the Hebrew Bible, Carr insists that Proverbs should be mined as a data source for this textual transmission process, as it »contains a wide range of materials that almost certainly were transmitted ... in the context of some form of ancient Israelite/Judean education. ${ }^{27}$ According to Carr, these sayings »served like lexemes in an internalized wisdom vocabulary ... those who had memorized this vocabulary could recombine elements from it in the process of forming new sayings. ${ }^{28}$ I do not intend to dispute Carr's broader theory, only to demonstrate how even such a theoretically informed reading perpetuates the assumption that Proverbs transparently reflects ancient educational practices.

In Early Israelite Wisdom Stuart Weeks maintained that the use of >wisdom literature senerally for reconstructing a notion of ancient Israelite education is speculative: »There is nothing in Proverbs which would have been of interest or use solely to a scribe ... the emphasis on the value of speech and persuasiveness ... need

22 Ibid.

23 Ibid., 52; 57; $58 \mathrm{f} . ; 61 \mathrm{f}$.

24 David Carr, Writing on the Tablet of the Heart (Oxford/New York: Oxford University Press, 2005) and more explicitly in The Formation of the Hebrew Bible (Oxford/New York: Oxford University Press, 2011), 25-36.

25 Carr, Writing on the Tablet of the Heart, 126.

26 Ibid.

27 Carr, The Formation of the Hebrew Bible, 25.

28 Ibid., 29. 
hardly be interpreted in terms of rhetorical skill. ${ }^{29}$ In his more recent Instruction and Imagery in Proverbs 1-9, Weeks challenged the correctness of the form-critical model driving a pedagogical reading of Proverbs. ${ }^{30}$ According to Weeks, the assumption of a pedagogical Sitz im Leben of Proverbs in scholarship results from the book's relationship to the ancient Near Eastern instruction genre. ${ }^{31}$ This particular form-critical assumption is flawed, Weeks argued, because these ancient Near Eastern instruction texts are fundamentally »)literary<... in the sense that they derive from written rather than oral prototypes. " 32 In summarizing his examination of the literary presentation of Proverbs 1-9, Weeks maintained, »It is questionable whether foreign instructions were designed for school use, but their use in schools would not in any case prove that Proverbs 1-9 must have been written with that function in mind. ${ }^{33}$ Weeks likewise recognized that the foreign instructions he examined all share the feature of a transmission and performance narrative frame, without using those specific terms. ${ }^{34}$ He further tied the sinstruction genre to the smemoriak genre, pointing to a shared feature: in both, discourse is articulated by a named individual, whose " prosperity in life confirms its value. « $^{35}$

While noting that the identity of the speakers in Proverbs is "vaguer « than in texts often compared to Proverbs, Weeks does not examine this important distinction. ${ }^{36}$ Further, his study is overly concerned with pointing to the swritten of instruction texts as a way of justifying their belletristic nature, that Proverbs cannot reflect a real-life context because the genre to which the book belongs the sinstruction genre - was always sliterary in the sense of written. ${ }^{37}$ In trying to avoid a form-critical reading of Proverbs, Weeks paradoxically perpetuates evolutionary assumptions lying at the heart of a form-critical reading. His attempt to controvert the oral origins of the instruction genre admits the fundamental correctness of the notion that a single real-life context determines the development of a literary form from its pure, simple oral state to a complex written state. ${ }^{38}$

29 Stuart Weeks, Early Israelite Wisdom (Oxford/New York: Oxford University Press, 1994), 156. 30 Stuart Weeks, Instruction and Imagery in Proverbs 1-9 (Oxford/New York: Oxford University Press, 2007), 2; 4 f.; 56-60; 65f.; 177-179.

31 Ibid., 177.

32 Ibid., $4 \mathrm{f}$.

33 Ibid., $177 \mathrm{f}$.

34 Ibid., 12.

35 Ibid., 10.

36 Ibid., 39-44.

37 Ibid., $4 \mathrm{f}$.

38 An example of this position is explicitly stated by Golka: »A proverb has to be explained primarily from its life situation, and only secondarily from its literary context«, in The Leopard's Spots, 15. 
One problem with identifying a purely written original context for the instruction genre is that its characteristic narrative frame of transmission depicts speech performance. For example, the individual instructions in Prov 1-9 are framed as a father's direct address to a son. Carol Newsom highlights this often neglected feature:

Very little attention is generally given to the significance of the fictional level established by [the father/son address]. It is a rather minimal fiction, but nonetheless important. The father who speaks, is the »I « of the discourse. The son, addressed in the vocative and with imperative verbs, is the "you. " Though other types of speech are occasionally embedded within it, the fiction never moves beyond this repeated moment of address. ${ }^{39}$

An examination of this "minimal fiction « however informs more than just a literary ideal for packaging and expressing wisdom and knowledge. While the performance of named and famed speakers in these texts is an artificial creation of the author, its use as a literary device suggests that oral performance - even its artificial representation in a written text - was the ideal mode to authorize claims.

The transmission of advice from sfather to sson « seems to be a ubiquitous trope in not only ancient Near Eastern instruction texts, but in the wider ancient Mediterranean. ${ }^{40}$ This trope likely draws upon deeply embedded values and social practices. ${ }^{41}$ It is especially evident that this form of presenting wisdom authorizing knowledge claims - was available to the authors of Proverbs since the instructions of Prov 1-9 are framed this way. ${ }^{42}$ And yet, the authors do not

39 Carol A. Newsom, »Woman and the Discourse of Patriarchal Wisdom: A Study of Proverbs 1-9, « in Gender and Difference in Ancient Israel, ed. Peggy L. Day (Minneapolis: Fortress Press, 1989): 142-160, 142 quoted.

40 Instruction performed by the father (biological or fictive) is the pedagogical method that the Stranger of Elea speaks of in Plato's Sophist: an oral instruction aimed at eliminating a particular kind of ignorance leading an individual to think that they know something when they in fact do not: »The venerable method of our fathers [archaioprepēs ti patrion], which they generally employed towards their sons, and which many still employ, of sometimes showing anger at their errors and sometimes more gently exhorting them - that would most properly be called as a whole admonition [nouthetētikēn], « Sophist 229c-230a. Plato in Twelve Volumes (1921).

41 See, for example, David Schloen, The House of the Father as Fact and Symbol: Patrimonialism in Ugarit and the Ancient Near East (Winona Lake: Eisenbrauns, 2001): »The patriarchal household is not simply an externally observable socioeconomic fact ... it is also a structuring symbol of social order that is comprehensible only in terms of the subjective meaningful motivations that give rise to patterns of social action «, 44 .

42 And, although the instructions of Prov 31,1-9 is framed as the speech of a mother, it is clear that this instruction is operating within the scope of speech-performance frame of a father's wisdom. 
frame Proverbs with the expected speech-performance narrative of transmitted wisdom, neither the work as a whole nor any of its sections attributed to the single named-and-famed figure from lore, Solomon. The fact that the biblical authors did not ımake Solomon speakı in Proverb's frame - a fact of the work's literary shaping - seems to cut against the most observable convention of the ancient Near Eastern instruction genre. And so, if we are to study the book of Proverbs against the background of these ancient Near Eastern instruction texts, as scholarship has done since the early 20th century, we should take such a comparison seriously and examine distinctive discrepancies between the self-presentation of Proverbs and these other texts.

\section{Textual frames and ideal performers of knowledge in ancient Near Eastern instruction compositions}

Since Erman's landmark article it has become a convention of biblical scholarship to understand the Book of Proverbs within the broader ancient Near Eastern sinstruction ‘ genre and to describe its literary function accordingly. ${ }^{43}$ Here we will focus on a brief description of the frames of three ancient sinstruction quently compared to Proverbs and one other which is less frequently compared: the Sumerian Instructions of Shuruppak, the Egyptian Instructions of Ptahhotep, and the Aramaic Instructions of Ahiqar fall into the former category, ${ }^{44}$ while Pirke Avot falls into the latter category. ${ }^{45}$ All four of these texts open with the narrative of the performance occasion and the identification of the performer. This performance occasion is configured differently in each text, but in all cases a named speaker is depicted as performing or having performed the decontextualized instructions to follow. The texts present themselves as performances of instruction from father to son (or instructor to instructed), which is a representation of

43 Erman, »Eine ägyptische Quelle ...«: 86-93. For a recent, detailed overview of past scholarship on the relationship between the Instructions of Amenemope and Prov 22,17-24,22, see Nili Shupak, »The Instruction of Amenemope and Proverbs 22:17-24:22 from the Perspective of Contemporary Research, « in Seeking Out the Wisdom of the Ancients: Essays offered to honor Michael V. Fox on the Occasion of his Sixty-Fifth Birthday, ed. Ronald L. Troxel, Kelvin G. Friebel and Dennis R. Magary (Winona Lake: Eisenbrauns, 2005): 203-220, here 203-217.

44 Scott, Proverbs and Ecclesiastes, xlii; xlviii-xlix; li-lii; McKane, Proverbs, 51-65; 155 (though he finds no reason to compare Shuruppak); 156-182; Richard J. Clifford, Proverbs: A Commentary (Louisville: Westminster John Knox Press, 1999), 9; 16-19.

45 See however James L. Crenshaw, who argues that the frame of Pirke Avot identifies the work as a direct heir to the ancient Near Eastern »wisdom tradition«: Old Testament Wisdom (Louisville: Westminster John Knox Press, ${ }^{32} 210$ ), 5. 
a single momentary event. This single performance event is however presented by the text as one within a series of previous and future events, a chain of transmission. These frames offer an ideal or model performance situation that socially locate their sinstructions ment in the world).

The Sumerian proverb collection known as the Instructions of Shuruppak, attests a third person narrated frame introducing the speaker of the proverbs themselves. ${ }^{46}$ This frame sets the performance of the selaborate words " in the distant past, identifies the speaker as Shuruppak »the wise one, « and provides a complete transmission narrative of the instructions from Shuruppak's father Ubara-Tutu to Shuruppak and from Shuruppak to his son Ziusudra. ${ }^{47}$ Shuruppak directly addresses Ziusudra and implores him to pay attention to his words. The narrated performance event contextualizes the words of the instructions themselves, assigning them to a speaker within a meaningful social setting. Further, these words are set within a transmission narrative that bespeaks the effectiveness of the instructions. Ziusudra's wisdom allowed him the immortality of the gods, according to the Sumerian flood account. If this is the tradition engaged in naming Ziusudra as the recipient of the Instructions, it is a testament to the effectiveness of the instructions: the words ensure the survival and success of one generation to reach the instruction of the subsequent generation. Moreover, the frame identifies an ideal performance situation where the instructions of Shuruppak, given to him by his own father, proved efficacious in the instruction of his son.

The frame narrative of the Egyptian Instructions of Ptahhotep opens with an anonymous frame speaker who introduces Ptahhotep who then speaks in his own voice to the king, requesting permission to pass his instruction to his

46 The oldest extant copy comes from the Early Dynastic period (ca. 2600-2500 BCE) and its subsequent copies attest to its continued transmission over a thousand years, including translations into Akkadian. See Bendt Alster, »Sumerian Canonical Compositions. C. Individual Focus. 1. Instructions, « in The Context of Scripture I: Canonical Compositions from the Biblical World, ed. William Hallo (Leiden/New York: Brill, 1997): 569.

47 See edition by Bendt Alster, The Instructions of Šuruppak, Copenhagen Studies in Assyriology 10 (Copenhagen: Akademisk Forlag, 1974). Wilfred G. Lambert argues that the figure of Shuruppak may have been a persona invented for the author of the frame, since Shuruppak does not appear in the Sumerian king list as an ante-diluvian king. It is in fact Shuruppak's father, according to the frame of the Instructions - Ubara-Tutu - who is listed as the last ante-diluvian king, not Shuruppak. Lambert further notes that recensions of Gilgamesh and Berossus make no mention of the person Shuruppak, suggesting that »the strange figure ... may have been invented soley to provide a teacher «, or that there may have been an alternate tradition of ante-diluvian history where Shuruppak was the last king of this period. See Babylonian Wisdom Literature (Winona Lake: Eisenbrauns, 1996), $93 \mathrm{f}$. 
son. ${ }^{48}$ This son, Ptahhotep hopes, will be able to internalize the "words of [those who] listen and the ideas of the ancestors « which are fading from his own heart, and in so doing, this son will take Ptahhotep's own place. ${ }^{49}$ The king authorizes this occasion of teaching and tells Ptahhotep to first teach him the skill of speech, so that this son may serve as a model for other children. ${ }^{50}$ The anonymous frame speaker then reintroduces Ptahhotep and his motive for speaking his instruction and stages the instructions to follow (lines 51-640) as words Ptahhotep said to his son. The frame of the Instructions of Ptahhotep thus serves to contextualize its instruction discourse as both a particular occasion of transmission from Ptahhotep to his son on the eve of his »retirement « as well as one occasion in a chain of performances between generations.

None of the ancient Near Eastern instruction texts we have discussed have as elaborate a frame narrative as the Instructions of Ahiqar. ${ }^{51}$ This text is framed

48 Miriam Lichtheim, Ancient Egyptian Literature, vol. 1: The Old and Middle Kingdoms (Berkeley: University of California Press, 1973), 76. Translation from ANET 412-414. While I do not provide an analysis of the many other Egyptian instruction texts, I will briefly note here that they all demonstrate versions of a frame that both identifies the speaker of the instruction and (even if laconically) describes a performance occasion. The Instructions of Meri-ka-re indicates that it is for the son of the speaker, unfortunately after this element of the frame the manuscript is broken, ANET 414-415 and Alexander Scharff, Der historische Abschnitt der Lehre für König Merikarê, SBAW 8 (München: Verlag der Bayerischen Akademie der Wissenschaften, 1936), $7 \mathrm{f}$. The Instruction of Amen-em-het is likewise framed as instruction, »a message of truth, « the eponymous speaker performs for his son, ANET 418. The Instruction of Hor-dedef is addressed to the speaker's son, ANET 419, as is the Instruction of Amenemope, whose scholarship is discussed in a previous note.

49 Lines $29 \mathrm{ff}$. Translation from ANET 412.

50 Line 39. ANET 412.

51 The earliest attested copy is a 5th c. BCE Aramaic text discovered at Elephantine. The structure of the narrative as presented here is taken from the many recensions of the text found in manuscripts dating to late antiquity and the Middle Ages. James Lindenberger presents a summary of the many iterations of the narrative. See The Aramaic Proverbs of Ahiqar (Baltimore/London: Johns Hopkins University Press, 1983). See also James Rendel Harris, Frederick C. Conybeare and Agnes Smith Lewis, The Story of Ahikar from the Aramaic, Syriac, Arabic, Armenian, Ethiopic, Old Turkish, Greek and Slavonic Versions (Cambridge: Cambridge University Press, revised and corrected editon ${ }^{2} 1913$ ). The Elephantine version consists of multiple papyri sheets, and it is difficult to determine where the narrative transitions to the instruction discourse, and in fact this may be because what we find in fact are multiple attempts at copying the frame narrative in the Elephantine text. For a recent study on the ordering of the papyri sheets see Seth Bledsoe, „Can Ahiqar Tell us Anything about Personified Wisdom?, «JBL 132 (2013): 119-137. The hand copy, edition, and translation of the Instructions of Ahiqar consulted in the present study are those published by Bezalel Porten and Ada Yardeni, Textbook of Aramaic Documents, Newly Copied, Edited and Translated into Hebrew and English, vol. 3 (Winona Lake: Eisenbrauns, 1993), 22-53. 
by a narrative of instruction performance and trans-generational transmission of knowledge, as the other Egyptian and Mesopotamian texts we have discussed. Yet there is something different about this particular frame story. Ahiqar is a story of the failure of wisdom's transmission. In the frame narrative, our protagonist is presented as the advisor to the great king. Ahiqar, early in his life, received an oracle that he would never have an heir. The wise advisor then adopts his nephew Nadin to be his successor and ensure the future transmission of his knowledge. This is the performance context given to the instructions, but this is not the conclusion of the narrative, which resumes at the end of the instructions. It is, in fact, not until the conclusion of the instructions where the drama of the narrative takes off. In the Instructions of Shuruppak or the Instructions of Ptahhotep, the narrative frame resumes at the end of the instructions, concluding the entire work by assuring the reader of the transmission of the knowledge to the ideal hearer, the "son" of the speaker. This concluding frame of transmission history also implicitly addresses the reader of the text, that a continuous chain of transmission from instructor to pupil, "father « to "son«, had been intact to reach the present reader. Such an explicit transmission chain we can see in the framing of the mishnaic tractate Pirke Avot. The tractate containing various instructions and wisdom opens with an extended narrative of transmission, a statement of the received authority of the text's discourse:

Moses received torah [instruction] at Sinai and transmitted it to Joshua, and Joshua to the elders, and the elders to the prophets, and the prophets to the men of the great assembly.

Avot closes with an explicit message to the recipient of the tradition on the timeline of internalizing scripture in a single lifetime and two aphorisms, one stating that the entirety of meaning can be found in Torah, and a second stating the fairness of the distribution of rewards. ${ }^{52}$ Pirke Avot, like other instruction texts, fulfills its aim through creating a context of the performance, past or future, of its instructions. Further, Avot's narrative frame necessarily engages the reader as a participant in this chain of tradition: its conclusion that one's efforts will be justly rewarded transcends the particulars of its advice to advance its ideal of Torah, writ large, and all the behaviors that such devotion entails. ${ }^{53}$

What is particularly notable about the framing of the Instructions of Ahiqar is that Nadin, filling the slot of the »ideal audience« to the speaker's wisdom, in fact turns against his uncle, Ahiqar. Nadin uses his wisdom to plot against his

52 Pirke Avot 5,22-3.

53 See Amram Tropper, Wisdom, Politics, and Historiography: Tractate Avot in the Context of the Graeco-Roman Near East (Oxford/New York: Oxford University Press, 2004), 48 f. 
uncle to usurp his place, but Ahiqar manages to outwit his nephew and in the end, Nadin, admonished by his uncle Ahiqar, dies. The chain of transmission is broken: Nadin will not pass Ahiqar's instructions to any heir. Nevertheless, the reader of the text is reading the instructions, so Ahiqar's wisdom managed to survive somehow. The failure of Nadin to internalize and transmit his uncle's wisdom in the narrative can be read as the narrator's transgression of the fiction of successive transmission of the instruction. The instruction texts previously discussed are legitimized as »time-honored wisdom « through the fiction presented in their narrative frame, that this instruction passes from ideal speaker to ideal hearer-cum-speaker through the generations until it reaches the reader of the text. The text stages a performance of instruction with this fiction of transmission in mind. In the Instructions of Ahiqar, the fiction of transmission is shattered by the failure of Nadin to symbolize the continuous transmission of Ahiqar's wisdom, and the medium of the text itself must (implicitly) fill the gap of the transmission to maintain the reader's fiction that this is that same time-honored wisdom of Ahiqar.

\section{Framing and speech performance in the book of Proverbs}

The frame narratives of the ancient Near Eastern instruction texts we have discussed above reflect the complex textuality of written instruction traditions. The utterances we have dubbed sinstructions tion and transmission in a mimetic representation of live speech performance. Yet as readers we encounter these performances through written texts that have, through a variety of strategies, staged a momentary (ideal) occasion of instruction and captured the potent personhood of a named (ideal) speaker. The presentation of the instructions' trans-generational transmission in the Instructions of Shuruppak and the Instructions of Ptahhotep implicitly maintains a fiction of the reader's participation in this transmission process. The frame of Pirke Avot prioritizes the chain of instruction transmission with an aim of including the reader as a participant in this transmission process. Finally, the frame narrative of the Instructions of Ahiqar seems to shatter the fiction of a performance transmission chain from ideal speaker to ideal hearer, reaching through the generations to the present reader of the text, by killing off the addressee of Ahiqar's instructions. In this case, while the instructions are still voiced by a speaker in the text, Ahiqar, the act of transmission is carried out implicitly by the medium of the text.

The Book of Proverbs reads like an anthology of multiple collections, each with their own title serving as the contextualizing frame for the decontextualized 
discourse which follows. The first, second, and fifth collections are all designated משלי שלמה, "מthe mashal-type discourse of Solomon «, ${ }^{54}$ and the third and fourth collections are designated דברי חכמים, »the dabar-type discourse of the Wise.«1 Unlike the instruction texts discussed above, none of these titles stage a performance context: they do not indicate an occasion of performance (transmission of knowledge to an heir or the advancing age of speaker), they do not indicate any type of addressee or destination for the discourse, and the named figure is not said in the title to engage in any sort of performance whatsoever. The discourse is the mashal-type or the dabar-type, but neither of these are said in the title to

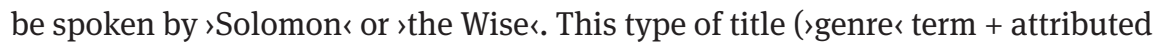
figure) is comparable in form to the title of Song of Songs, headings in Psalms, and those titles attributing rauthorship to collected prophetic materials. ${ }^{56}$ These titles in Proverbs are both formally and functionally different than the frames of the ancient Near Eastern instruction texts we have examined above, because they do not stage a performance of the named figure, and it is not clear from the titles who is in fact speaking these texts apart from the text itself.

This, of course, does not mean there are no speakers in Proverbs. It is true that the multiple sections in Prov 1-29, traditionally dubbed the ssentence literature,${ }^{57}$ are on the whole decontextualized utterances without a speaker or performance context. Other sections of Proverbs are, however, grounded in speech

54 I leave the term mashal here untranslated, as its translation is tied up in a complex problem of history of the study of biblical poetics and our own imposed categories, and thus beyond the scope of the present article. For a treatment of this issue, see my recent doctoral dissertation, "Proverbs and the Limits of Poetry" (University of Chicago, 2015). The three mashal-type collections are Prov 1-9; 10-22,16; 25-29, with titles in Prov 1,1; 10,1a; 25,1.

55 The title in Prov 22,17 is reconstructed based on the title in Prov 24,23, »these too are of the Wise

56 The formula of the titles is a genre term (plural or singular) in construct with the PN of the attributed figure, and sometimes this formula is extended with a patronymic (Solomon, son of David, king of Israel). There is great variety in the titles in Psalms, and their terms, titles, or referents are not well understood. See the classic study of Sigmund Mowinckel who saw the titles as information for the cultic setting and performance of the Psalm, The Psalms in Israel's Worship, trans. Dafydd R. Ap-Thomas (New York: Abingdon Press, 1962), 76-78; 207-217. Titles on the collections of the Latter Prophets are comparable to those found in Proverbs, Ecclesiastes, and the Psalms, that is, there is no description of the act of specifically speech performance in many of these titles (compare, for example, Ob 1,1, »The vision [חז of Obadiah« to Isa 1,1, »The vision [חזון] of Isaiah son of Amoz who envisioned/prophesied [חזה] about Judah and Jerusalem ...«). Some of these titles are explicitly textual in their reference, such as Nah 1,1: »A pronouncement [משא] on Nineveh: the scroll of the vision [חזון] of Nahum the Elkoshite." 57 Von Rad, Wisdom in Israel, 26. 
performance to varying degrees..$^{58}$ Prov 1-9 features ten speeches framed as instruction performances from stock characters, speaking ,fathers addressing attentive >sons « who never respond..$^{59}$ Prov 1-9 also features the speech performance of feminine voices, personified Wisdom and Folly. ${ }^{60}$ Yet this inner framing of speech resists the contextualization characteristic of the ancient Near Eastern instruction texts, because none of these figures are named and identifiable from the literary tradition. Reading Prov 1-9 against the background of the framing of the Instructions of Shuruppak, the Instructions of Ptahhotep, and the Instructions of Ahiqar as wisdom performed by identifiable ideal figures of wisdom, we are forced to ask basic questions of text presentation: If these discourses in Prov 1-9 are the mashal-performances of Solomon, then why does Solomon not perform any of them? If Solomon is not a performer of mashal, as he is in I Kings 5,12 (»He spoke three-thousand mashal ..."), then how exactly are we to understand Solomon's role in the text?

58 Prov 30 and 31 are both framed by titles which identify speakers (Agur and Lemuel's mother, respectively) and describe speech performance. While these may be examples of framing reminiscent of the ancient Near Eastern instruction texts, neither of these figures are known from biblical lore, outside of their appearance here in Proverbs. While their obscurity may be only a function of our reception of the literature as strangers to the literary tradition out of which these texts emerged, it remains a fact that within the biblical tradition in its present form, the attribution of instruction ` to such figures communicates little to the reader and lends no legitimacy to the discourse. The attributions of Prov 30 and 31 to Agur and Lemuel's mother do not carry the same authorizing force as the attribution of Prov 1-9, 10-22,16, and 25-29 (and the entire work in its present form) to Solomon, whose persona carries significant weight of literary tradition.

59 Prov 1,8, »Listen, my son, to the discipline of your father / do not forsake the instruction of your mother //«; Prov 2,1, »My son, if you accept my words / my commandments, you treasure up //«; Prov 3,1, »My son, my instruction, do not forget / my commandments, let your mind retain // «; Prov 3,21a, »My son, do not lose sight of them ...«; Prov 4,1a, »Listen sons, to the discipline of a father...«; Prov 4,10a, »Listen, my son, and take in my words ... «; Prov 4,20, »My son, listen to my utterances / to my words incline your ear //«; Prov 5,1, »My son, to my wisdom listen / to my insight incline your ear //«; Prov 6,20, »My son, keep your father’s commandment / do not forsake your mother's instruction//«; Prov 7,1, »My son, heed my words / my commandments, store up with you //.«

60 >Lady Wisdom speaks in extended, staged discourses in the following passages: Prov 1,22-33, and the speech performance framed by third-person introduction in 1,20-21; Prov 8,4-36 (v. 11 is the only utterance in this speech which breaks the first-person discourse of Lady Wisdom, referring to wisdom in the third-person), and the speech performance is framed in 8,1-3. Lady Wisdom speaks in the midst of more extended framing in Prov 9,4a, 5-6, framed by 9,1-3; Lady Folly speaks in an extended narrative frame in Prov 7,14-20, framed by a first-person anonymous narrator in 7,6-13, and Lady Folly speaks again in a non-narrative, descriptive frame, Prov 9,16a-17. 
One way to begin to address these questions is to understand Proverbs' final shaping as a response to the literary tradition in which the book participates. These questions bear directly upon our configuration of the relationship between the poetics of the Book of Proverbs (the values articulated by its self-representation) and its social role as a literary work (what the work does for its audience). Fox, who admits the cacophony created in the collection of these various voices, argues that the voice of Lady Wisdom is advanced as this single, unifying voice to subsume these other voices, »even [the voice] of Solomon himself«, that this cacophony "speaks with a single voice, and this is Wisdom's own «. ${ }^{61}$ If this is so, then why are three of the major sections attributed to Solomon, yet he does not join this cacophony of voices as a speaker? Moreover, why are none of the speakers identifiable from biblical lore? Fox's argument, that more than any voice in Proverbs it is Wisdom who speaks, begs reconciliation not only with the frame's implication that text performs and transmits the discourse, but that an abstract personified quality, Wisdom, can socially function as an ideal instructor. The other ancient Near Eastern instruction texts examined above advance an idea that instruction is transmitted through the (textually represented) oral performance of authorized figures, (human) individuals with a reputation for great wisdom. By contrast, the Book of Proverbs stages its discourse either in the mouths of abstract or stock figures (Wisdom, the sfather`) or, broadly, constructs the text itself as the voice of these speeches. The notion that text teaches is not part of the fiction framing instruction in the Instructions of Shuruppak or the Instructions of Ptahhotep, and only implicitly in the transmission assumptions for the Instructions of Ahiqar, but the voice of the textual medium is an effect of the minimal framing and attribution of Proverbs.

We should therefore reconsider our treatment of Proverbs in painting a picture of sancient Israelite education.` Our reconstruction of the ancient social context should be preceded by an examination of the values advanced by the book's presentation of knowledge production and discourse. Does the Book of Proverbs reflect normative views of ancient educational values and instructions - if something >normative can even be notionally reconstructed? This study has shown that ancient Near Eastern instruction texts represent and authorize their discourse through a renowned, ideal speaker, while Proverbs does not. Literary conventions demonstrate a complex relationship with social realities and do not transparently reflect actual practices. On the one hand, the fact that knowledge-claims are presented, even fictionally, in instruction texts as speech performance points to a shared value: speakers have unique authority to trans-

61 Michael V. Fox, Proverbs 1-9, AB 18a (New York: Double Day, 2000), 359. 
mit knowledge. These works engage this shared value in ensuring the esteem and survival of their often decontextualized claims. Such a value for performed speech seems to draw upon operative social principles, since certain categories of individuals - kings and fathers - authorize these performances. This is especially evident in the framing of individual units of Proverbs, where it is not the reputation of a single individual whose performance authorizes the speech, but the generic category of an individual - the father - who is the named speaker.

On the other hand, this authorizing device - the presentation of speech in the mouth of a socially authoritative individual, named or unnamed - is a literary trope. We cannot conclude from such a literary presentation of the instructions in Prov 1-9 that fathers in ancient Israel and Judah educated their sons with such speeches, or that the lack of such a frame for larger units and the book as a whole indicates the decline of such a practice. This study has aimed to reposition the examination of Proverbs against the broader ancient Near Eastern tradition of instruction text-making as a study of the reshaping of literary values. It is true that the biblical text does not explicitly theorize its literary culture in a manner recognizable to those inculcated in Western literary theory. However, by virtue of its participation in a wider literary tradition, the biblical text does express positions on values espoused by this tradition. In the case of Proverbs, we may be able to consider how its use of framing devices reshapes the traditions of authorizing knowledge, by shifting authority from a fictional moment of speech performance to the enduring presence of the text itself.

Abstract: The study challenges the use of the book of Proverbs as a primary data set in the recovery of ancient Israelite and Judean educational values and practices. The study argues that an examination of the nature of the Book of Proverbs and its poetics must necessarily precede the use of this text in reconstructing the values and practices of ancient Israelite and Judean education. Although Proverbs can and has been compared to ancient Near Eastern instruction or >wisdom< texts, the study demonstrates how the frame of Proverbs is distinct from the frames of these other texts. The study further argues that the Book of Proverbs in its framing and poetics articulates a specific and idiosyncratic position on formal speech performance and the value of participating in such an activity.

Résumé: Cette étude met en question l'usage du livre des Proverbes comme source d'information première dans la recherche des valeurs et des pratiques éducationnelles des anciens Israélites et Judéens. Elle défend que l'examen de la nature du livre des Proverbes et de sa mise en forme littéraire doit précéder l'emploi de ce texte pour la reconstruction des valeurs et des pratiques des anciens Israélites et 
Judéens en terme d'éducation. Bien que le livre peut et a été comparé à des textes d'instruction ou de « sagesse » du Proche-Orient ancien, l'étude montre comment la structure des Proverbes est distincte de celles de ces autres textes.

Zusammenfassung: Die Studie wendet sich dagegen, das Buch der Sprüche als Primärquelle für eine Rekonstruktion der erzieherischen Werte und Praktiken des alten Israel und Juda zu gebrauchen. Sie argumentiert, dass einer Nutzung des Textes zu einer solchen Rekonstruktion notwendigerweise eine Untersuchung des Charakters des Sprüchebuchs und seiner Poetik vorangeschickt werden muss. Obwohl die Sprüche mit altorientalischen Belehrungen und Weisheitstexten verglichen werden können und müssen, zeigt die Studie, wie sich der Rahmen des Sprüchebuches von demjenigen solcher Texte unterscheidet. 